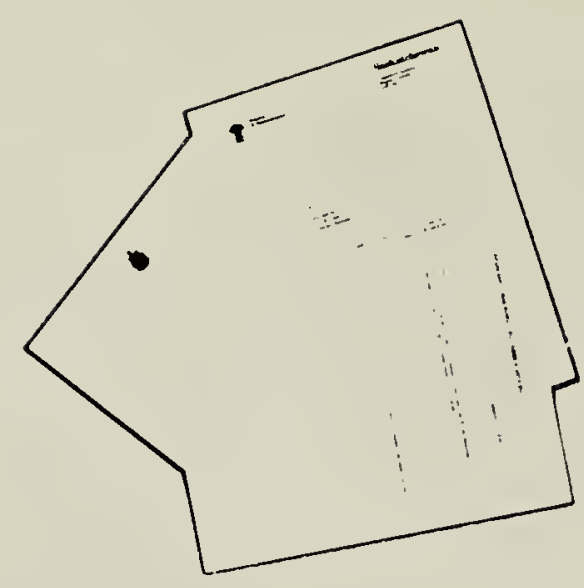

\section{FALCONS AND MAGPIES}

On December 7, 1977, a cold cloudy day with a light easterly wind, a Prairie Falcon gave chase to the farm pigeon flock. The pigeons flew immediately to the small coop in which they stay, but as there were only four entrance holes, $4^{\prime \prime} \times 6^{\prime \prime}$, all the birds could not enter in time, so several sought refuge by dropping to the ground and under trees that surround the building. The falcon would circle the area and sometimes hover above the coop, making sudden dives at birds not well hidden.

Magpies immediately began gathering, flitting from tree to tree and not seeming too concerned about the falcon; one even flew up beside the falcon as he hovered some 15 feet above the coop, but the falcon paid no heed to it.

Now, I wonder, are magpies bad tasting? or what is the reason most hawks do not consider them as food?

A few years back, I saw magpies gather around a Gyrfalcon that had captured a pigeon and as he was busily plucking it, one magpie walked boldly up behind and tugged at his long flight feathers. I have found magpie feathers in Swainson's Hawk and horned owl nests, and once saw a Swainson's Hawk carrying a young magpie to his nest. But falcons seldom pay any attention to them. The magpie is a slow flyer, often travels across open fields and, so would be vulnerable to the falcon, but there seems to be some kind of a truce between them.

I have noticed that cats have to be very hungry before they will eat a magpie. In early December a magpie became trapped in a chicken pen so I

\section{LETTERS}

disposed of it and when I was carrying it away, a young cat that is perpetually hungry came running. I pulled the feathers off the breast and dropped the bird to the cat, who attacked it greedily. Later I came back and the magpie had hardly been touched. The cat, after tasting it, had left it. Had this been a partridge or a pigeon, I am sure it would have been entirely eaten. Sig Jordheim, White Bear, Saskatchewan.

\section{COUGAR SIGHTINGS}

I have three cougar sightings to report. The first cougar was seen by myself on July 20,1977 at 1030 beside the road on SE-17-9-20-W3rd. The second was seen by Ralph Stoneman on July 29, 1977 at 1600 beside a barn on SE-18-9-21-W3rd. And on August 16, 1977 at 1430 I again saw a cougar on the roadside on SW-16-9-20-W3rd.

This last cougar was a female, and she must have been nursing young because she appeared to have two full udders.

All three sightings were at close range. The two I saw were within 50 to 60 feet away, and they didn't run away when I stopped the car. Each time the animal still stood and watched as I drove away. Doreen Kemper, Box 368, Shaunavon, Saskatchewan SON $2 \mathrm{MO}$.

\section{LAZULI BUNTING NEAR LANGHAM}

In their article on Lazuli Buntings in Saskatchewan (September, 1977, Blue Jay), Ron Jenson and Don Weidl request comments on other ob- 


\section{servations.}

On May 14, 1976, I watched for 10 minutes three Lazuli Buntings, a male and two females, perched or flying around a barbed wire fence beside a slough 4 miles west of Langham, Saskatchewan, along the Edmonton highway. My observation was close and detailed enough to leave no room for doubt. I also have a colour photograph.

Because I did not realize that the species was so infrequent in Saskatchewan, the observation has not hitherto been put on record. W.A.S. Sarjeant, Department of Geological Sciences, University of Saskatchewan, Saskatoon, Saskatchewan. S7N 0W0.

\section{FROM A PENNED OWL}

I am a large owl with large eyes, the colour of which I do not know, but I have keen hearing with my small ears. I am fluffy and keep quite warm in the winter months with my abundance of grey and brown feathers. I have quite ong and strong legs and talons, but when I'm resting, I look like I'm sitting on my body with no legs at all! I must veight about 4 pounds, and when I'm lying my wing span is over 4 feet. I can ly silently and swiftly. At present my ex is unknown, and so I can't tell you whether I'm male or female.
For the last 4 or 5 years I have been a resident of that much publicized and notorious institution, the Saskatchewan Penitentiary - by choice, not by conviction. I stay mostly within the confines of the massive New Shops Dome area, where most of the industrial activity is carried out by staff and inmates.

No one sees me in the daytime, for I keep well hidden in the upper, forbidding superstructure of "The Dome". But at night, Oh Boy, do I ever do my thing, when the spirit moves me. Occasionally I fly to the top of the high wall that surrounds "The Establishment". One evening recently, I flew from the roof of the Tailor Shop to a spot about 15 feet from the West Wall Tower, on the north side. The officer in the tower studied me closely with binoculars for about 10 minutes; then I returned to the Tailor Shop. Twenty minutes later, I flew to the high roof of the Boiler House, where I frightened some pigeons that roost there. The resulting tumult of cries and coos drew the attention of the yard patrol officer and his shepherd dog, and by the time the officer tried to drive me off with sticks and stones, and with the dog barking loudly, I'm sure every man and beast in the area was wide awake. So far I haven't been hit with the missiles, and the Yard Officer hasn't shot at me with his .38

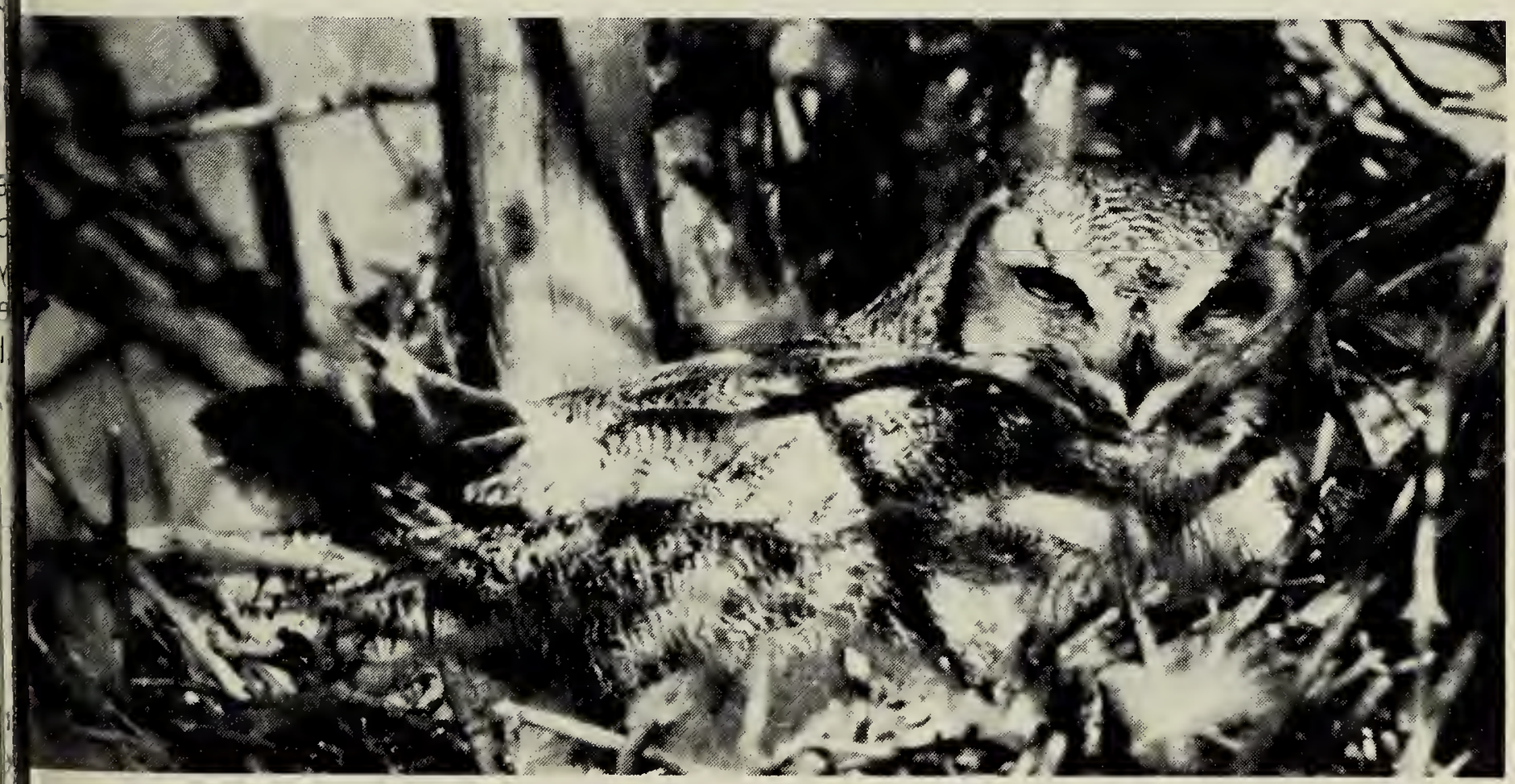


Special, or worse still, that Tower Officer with his high powered rifle. If they did, I might end up on the endangered species list. But the yard man was only trying to protect the pigeons, and the Tower Officer showed a genuine interest in me. He is writing a story about me, and I hope his description is vivid, because I feel I'm important. And just like the other inhabitants of the Pen, I may remain here a long time, providing I don't make that unsavory endangered list.

I hope I have properly introduced myself to you. Until we meet again, take care, and I'll say what I say to everything and everyone else around here - "Hoo, Hoo to you too"! Cordon B. Kennedy, 789 22nd St. East, Prince Albert, Saskatchewan S6V 1 N9

\section{WESTERN SANDPIPER CORRECTION}

I'm writing in regard to a sighting of a Western Sandpiper which I made in Saskatchewan a few years ago. The sighting was reported in "Highlights of Saskatoon Observations 1970-1974" by Stan Shadick, Blue Jay 33:165-168. There are a couple of errors in the text which I would like to correct. Firstly, the bird was noted to have a "rusty cap and back" not a "rusty crown and cap". Secondly, the bird was seen at Vanscoy Lake (near Purdue) not at $V$ anscoy, and is, therefore, 5 miles west of the Saskatoon area as defined by the Saskatoon Natural History Society. Details of the sighting are correctly reported in Renaud and Renaud's Birds of Rosetown-Biggar - Al Smith, 1110 10025 Jasper Ave., Edmonton, Alberta.

\section{COLONIAL BIRD REPORTS SOUGHT}

This summer I will again be conducting a survey of white pelicans and double-crested cormorant colonies in Saskatchewan. I would appreciate any nesting reports for these birds.

I am also interested in receiving breeding records for all colonial nesting species of herons, grebes, gulls, and terns. Data should include th location and size of the breedin colony.

Please send information to:

Keith Roney,

Museum of Natural History, College and Albert St.,

Regina, Saskatchewan S4S 0B3

\section{PRAIRIE NEST RECORD REPORT AVAILABLE}

The Prairie Nest Record Schem report for the 1977 nesting season available on request. Also, person interested in becoming contributors $t$ this program can obtain informatio and recording cards by writing to:

H. W. R. Copland

Prairie Nest Record Scheme

c/o Manitoba Museum of Man an Nature

190 Rupert Avenue

Winnipeg, Manitoba R3B 0N2

Information recorded on nestin birds is used by federal and provincia biologists, people doing environment impact studies, university studen working on research projects, etc.

\section{PLAINS AQUATIC RESEARCH CONFERENCE}

The Water Studies Institute and th Dept. of Extension of the University Regina are planning to hold a two-de conference in Regina in the fall 1978. The conference will be devote to aquatic research and its applicatic in the plains environment and pape related to any aspect of that them will be invited. The conference intended, not only for researchers, bi also professionals an paraprofessionals. If you are terested, write for information to:

Dept. of Extension, Univ. of Regina, Room 113, College Bldg.,

College Avenue \& Scarth Street, Regina, Saskatchewan S4S 0A2 